\title{
KEBIASAAN SARAPAN DAN KONSENTRASI BELAJAR MAHASISWA
}

\author{
I Gede Purnawinadi ${ }^{1}$, Christa Vike Lotulung ${ }^{2}$ \\ ${ }^{1}$ Fakultas Keperawatan, Universitas Klabat, Airmadidi-Minahasa Utara 95371, Indonesia \\ ${ }^{2}$ Fakultas Keguruan dan Ilmu Pendididkan, Universitas Klabat, Airmadidi-Minahasa Utara 95371, Indonesia \\ Email: purnawinadi87@unklab.ac.id
}

\begin{abstract}
Breakfast is useful to meet the energy needs of the body, especially the brain requires nutrition in improving the ability to concentrate in learning. This study aims to analyze the relationship between breakfast habits and the concentration of learning in students at Klabat University. This type of research is an analytic survey through a cross sectional approach which was conducted on 177 general English 1 class students who were selected using a purposive sampling technique. The questionnaire was used to obtain data on breakfast habits and concentration of learning. Analysis of the relationship between variables using the Spearman Correlation test. The results showed that the dominant students rarely had breakfast (39\%) and high learning concentration (56.5\%). There was a very weak but significant relationship between breakfast habits with the level of student learning concentration $(r=0.162$ and $p=0.031)$. Students awareness about the importance of breakfast needs to be increased through socialization in the classroom and outside the classroom.
\end{abstract}

Keywords: breakfast habit, learning concentration, students

\section{Abstrak}

Sarapan bermanfaat memenuhi kebutuhan energi tubuh terlebih otak memerlukan gizi dalam meningkatkan kemampuan konsentrasi dalam belajar. Penelitian ini bertujuan untuk menganalisis hubungan kebiasaan sarapan dengan konsentrasi belajar pada mahasiswa di Universitas Klabat. Jenis penelitian ini merupakan survei analitik melalui pendekatan cross sectional yang dilakukan pada 177 mahasiswa kelas general english 1 yang dipilih menggunakan teknik purposive sampling. Kuesioner digunakan untuk memperoleh data kebiasaan sarapan dan konsentrasi belajar. Analisis hubungan antar variabel menggunakan uji Korelasi Spearman. Hasil penelitian menunjukkan bahwa dominan mahasiswa jarang sarapan (39\%) dan konsentrasi belajar tinggi (56,5\%). Terdapat hubungan yang sangat lemah namun bermakna antara kebiasaan sarapan dengan tingkat konsentrasi belajar mahasiswa $(r=0,162$ dan $p=0,031)$. Kesadaran mahasiswa tentang pentingnya sarapan perlu ditingkatkan melalui sosialisasi di kelas maupun di luar kelas.

Kata kunci: kebiasaan sarapan, konsentrasi belajar, mahasiswa 


\section{PENDAHULUAN}

Pemuda merupakan harapan masa depan bangsa sebagai sumber daya manusia yang berkualitas dan berguna bagi masyarakat. Upaya pencapaian sumber daya manusia berkualitas lebih difokuskan pada pembentukan manusia yang mampu hidup sehat serta mempunyai kesempatan hidup dalam kesejahteraan (Nurhadi, 2016). Peningkatan derajat kesehatan masyarakat tentu diperlukan dalam mengisi upaya dalam mencapai tujuan pembangunan bangsa melalui perbaikan gizi masyarakat yang dilakukan salah satunya adalah kegiatan makan pagi atau sarapan. Makan pagi atau sarapan berperan sangat penting untuk pemenuhan gizi dipagi hari, lebih khusus pada peserta didik mempunyai aktivitas yang sangat padat secara akademis (Arifin dan Prihanto, 2015).

Sarapan yang rutin berguna untuk memenuhi kebutuhan energi dalam tubuh dalam melakukan aktivitas yang optimal. Kegiatan tersebut sangat penting terutama bagi para peserta didik karena dapat mendukung pertumbuhan dan perkembangan serta berbagai aktivitas dalam pendidikan (Wiarto, 2013). Energi diperoleh dari makanan dan minuman yang dikonsumsi. Tidak sarapan menyebabkan peserta didik kurang berenergi karena perut kosong sehingga menjadi susah untuk fokus berpikir saat belajar, hal tersebut sangat mempengaruhi prestasi belajar (Sukiniarti, 2015).

Pagi hari otak sangat memerlukan zat gizi akibat puasa semalaman karena tidur. Sarapan dapat memenuhi kebutuhan kadar gula dalam darah (Evans, 2009). Energi yang digunakan waktu tidur berasal dari cadangan kalori yang tersimpan dalam tubuh, jika cadangan energi di dalam tubuh habis, suplaia ke otak akan berkurang, sehimgga membuat tubuh menjadi lemas, kepala pusing, keluar keringat dingin, bahkan tidak pingsan karena kekurangan energi. Selain itu pula daya ingat dan berpikir akan berkurang, hal ini mengakibatkan kemampuan bekerja otak semakin lemah dalam aktivitas setiap hari. Untuk itulah di perlukan energi yang cukup sebagai bahan bakar bagi otak untuk berkerja. Unsur zat gizi yang terkandung dalam makanan saat sarapan sangat bermanfaat dalam memenuhi kecukupan gizi dibanding makanan jajanan (Faizah, 2014). Hardinsyah \& Aries (2012) menyatakan bahwa 15-20\% kebutuhan energi total setiap hari dapat terpenuhi dengan melakukan sarapan.

Prestasi belajar mahasiswa dipengaruhi oleh berbagai faktor diantaranya adalah konsentrasi. Aktivitas belajar membutuhkan konsentrasi dalam mencapai suasana belajar yang kondusif, sehingga meningkatkan kemampuan kognitif yang baik. Kemampuan belajar dengan konsentrasi yang tinggi mempunyai peran dalam peningkatan prestasi belajar (Setiawan \& Haridito, 2015). Konsentrasi merupakan kemampuan dalam memfokuskan pikiran, kemauan, perasaan, dan segenap panca indera pada satu obyek dalam satu aktivitas tertentu, dengan tidak terpengaruh oleh obyek-obyek lain yang tidak berhubungan dengan aktivitas tersebut (Winata, 2015).

Meskipun sarapan pagi merupakan program secara nasional, sebagian masyarakat Indonesia masih belum mengetahui manfaat sarapan pagi sehingga tidak melakukan sarapan pagi sebelum beraktifitas. Survei awal yang dilakukan peneliti pada beberapa mahasiswa di kelas General English 1 di Universitas Klabat, mayoritas mengatakan bahwa setiap pelajaran berlangsung mereka mudah merasa bosan, mengantuk, merasa lapar sehingga sulit berkonsentrasi dan beberapa mahasiswa mengaku tidak sarapan pagi sebelum berangkat kuliah. Banyak faktor yang menyebabkan hal tersebut, diantaranya kemampuan finansial, tidak adanya kesempatan 
sarapan karena sibuk bekerja, tidak ada waktu cukup untuk sarapan karena aktifitas kuliah pagi hari, terlambat bangun pagi, bahkan mengeluh merasa sakit perut saat sarapan. Berdasarkan fakta sebagai latar belakang yang telah dibahas, peneliti termotivasi dalam melaksanakan penelitian yang bertujuan untuk menganalisis hubungan kebiasaan sarapan dengan konsentrasi belajar mahasiswa di Universitas Klabat.

\section{METODE}

Penelitian ini merupakan survei analitik menggunakan pendekatan rancangan cross sectional. Penelitian dilaksanakan di Universitas Klabat Airmadidi Manado pada bulan Februari sampai Maret 2020. Besar sampel 177 mahasiswa dipilih melalui teknik purposive sampling pada kelas General English 1 semester genap tahun ajaran 2019-2020. Sampel dipilih berdasarkan kesediaan dan kehadiran mahasiswa di kelas saat penelitian dilakukan.

Data kebiasaan sarapan diperoleh melalui kuesioner penelitian yang dibagi menjadi 4 kategori, yaitu selalu (2 kali seminggu), sering (4-6 kali seminggu), jarang (1-3 kali seminggu), dan tidak pernah, disertai alasan responden jarang dan tidak sarapan. Tingkat konsentrasi belajar mahasiswa dinilai menggunakan kuesioner yang dibuat peneliti yang terdiri dari 20 pertanyaan terkait konsentrasi belajar dengan empat pilihan jawaban yaitu selalu (jika mengalami atau melakukannya setiap hari kuliah), sering (jika jawaban lebih banyak ya dibanding tidak), jarang (jika jawabana lebih banyak tidak dibanding ya), dan tidak pernah (jika tidak pernah sama sekali mengalami/melakukannya). Kategori dan nterpretasi konsentrasi belajar dapat dilihat pada tabel 1.

Tabel 1. Interpretasi Konsentrasi Belajar

\begin{tabular}{ccc}
\hline Kategori & Interval Skor & Interpretasi \\
\hline 1 & $15-23$ & sangat rendah \\
2 & $24-32$ & rendah \\
3 & $33-41$ & sedang \\
4 & $42-50$ & tinggi \\
5 & $51-60$ & sangat tinggi \\
\hline
\end{tabular}

Peneliti melakukan pilot study pada 61 mahasiswa di kelas yang berbeda untuk menguji validitas dan reliabilitas kuesioner yang digunakan dalam pengumpulan data penelitian, dengan hasil yaitu hanya 15 pertanyaan yang memenuhi kriteria valid dan reliabel dengan nilai Cronbach's Alpha 0,765.

Pelaksanaan penelitian ini menerapkan prinsip etika autonomy, yaitu tanpa pemaksaan dimana responden mempunyai hak untuk ikut serta ataupun tidak bersedia menjadi responden dengan bersikap adil (justice) tanpa memihak pada sebagian responden saja. Penelitian ini tentunya bertujuan baik dalam upaya menelaah hubungan kebiasaan sarapan pagi dengan kemampuan konsentrasi belajar mahasiswa, sehingga prinsip beneficience nyata dalam penelitian ini. Dalam pelaksanaan penelitian ini sedapat mungkin peneliti menghindari hal-hal yang berbahaya dan merugikan, sehingga prinsip non-maleficience dapat diterapkan, begitu pula coefidentiality sangat dijunjung sebagai suatu kerahasiaan dan melindungi data informasi responden hanya untuk kepentingan penelitian.

Pengolahan data dilakukan melalui tahapan editing, coding, processing, dan cleaning. Analisis data secara univariat dilakukan untuk mengetahui gambaran distribusi frekuensi masing-masing variabel yang diteliti, sedangkan analisis bivariat untuk mengidentifikasi adanya hubungan yang signifikan antara kebiasaan sarapan dengan konsentrasi belajar mahasiswa dalam bentuk data berskala ordinal melalui uji statistik non-parametrik Spearman Correlation dengan tingkat kemaknaan $95 \% \quad(\alpha \quad 0,05)$ menggunakan aplikasi program komputer berupa Statistical Program for Service Solution (SPSS). Keeratan hubungan antara variabel digunakan kriteria koefisien korelasi seperti pada tabel 2 .

Tabel 2. Keeratan Hubungan antara Variabel

\begin{tabular}{cc}
\hline Koefisien Korelasi $(\mathrm{r})$ & Interpretasi \\
\hline $0,00-0,19$ & Sangat Lemah \\
$0,20-0,39$ & Lemah \\
$0,40-0,59$ & Sedang \\
$0,60-0,79$ & Kuat \\
$0,80-1,00$ & Sangat kuat \\
\hline
\end{tabular}

Sumber : Sugiyono (2012) 


\section{HASIL PENELITIAN}

Hasil penelitian ini menggambarkan distribusi frekuensi dan hubungan variabel penelitian, yaitu kebiasaan sarapan dan konsentrasi belajar mahasiswa.

Tabel 3. Distribusi Frekuensi Kebiasaan Sarapan

\begin{tabular}{lcc}
\hline Kategori & Frekuensi & Pesen (\%) \\
\hline Tidak pernah & 27 & 15,2 \\
Jarang (1-3 seminggu) & 69 & 39 \\
Sering (4-6 seminggu) & 60 & 33,9 \\
Selalu (setiap hari) & 21 & 11,9 \\
Total & 177 & 100 \\
\hline
\end{tabular}

Hasil penelitian terhadap 177 responden yang ditampilkan pada tabel 3 bahwa 69 orang (39\%) jarang sarapan, 60 orang $(33,9 \%)$ sering sarapan, 27 orang $(15,2 \%)$ tidak pernah melakukan sarapan dan responden yang selalu melakukan sarapan hanya 21 orang $(11,9 \%)$.

Tabel 4. Distribusi Frekuensi Alasan Jarang dan Tidak Sarapan

\begin{tabular}{lcc}
\hline Alasan & Frekuensi & $\begin{array}{c}\text { Persen } \\
(\%)\end{array}$ \\
\hline Selalu dan sering sarapan & 81 & 45,7 \\
Kuliah jam 7 pagi & 28 & 15,8 \\
Terlambat bangun pagi & 29 & 16,4 \\
Tidak terbiasa sarapan pagi & 23 & 13 \\
Sakit perut jika sarapan pagi & 6 & 3,4 \\
Malas & 6 & 3,4 \\
Tidak sesuai selera & 1 & 0,6 \\
Kerja pagi (labor) & 3 & 1,7 \\
Total & 177 & 100 \\
\hline
\end{tabular}

Tabel 4 menunjukkan distribusi frekuensi beberapa alasan responden yang jarang dan tidak sarapan. Terlambat bangun pagi merupakan alasan yang dominan yaitu 29 orang (16,4\%), kemudian diikuti dengan alasan kuliah jam 7 pagi 28 orang $(15,8 \%)$, tidak terbiasa sarapan 23 orang $(13 \%)$, merasa sakit perut jika sarapan dan malas masing-masing 6 orang $(3,4 \%)$, kerja pagi (labor) 3 orang $(1,7 \%)$, dan tidak sesuai selera 1 orang $(0,6 \%)$.
Tabel 5. Distribusi Frekuensi Konsentrasi Belajar Mahasiswa

\begin{tabular}{lcc}
\hline Kategori & Frekuensi & Pesen (\%) \\
\hline Rendah & 2 & 1,1 \\
Sedang & 63 & 35,6 \\
Tinggi & 100 & 56,5 \\
Sangat tinggi & 12 & 6,8 \\
Total & 177 & 100 \\
\hline
\end{tabular}

Gambaran konsentrasi belajar dari 177 responden dapat dilihat pada tabel 5 . Terdapat 100 orang $(56,5 \%)$ konsentrasi tinggi, 63 orang $(35,6 \%)$ konsentrasi sedang, 12 orang $(6,8 \%)$ konsentrasi sangat tinggi, dan hanya 2 orang $(1,1 \%)$ konsentrasi rendah.

Tabel 6. Hubungan Kebiasaan Sarapan dengan Konsentrasi Belajar

\begin{tabular}{|c|c|c|c|}
\hline Spearman's rho & & $\begin{array}{l}\text { arapan } \\
\text { agi }\end{array}$ & Konsentrasi \\
\hline \multirow[t]{3}{*}{$\begin{array}{l}\text { Sarapan } \\
\text { pagi }\end{array}$} & $\begin{array}{l}\text { Correlation } \\
\text { Coefficient }\end{array}$ & 1.000 & $.162^{*}$ \\
\hline & $\begin{array}{l}\text { Sig. } \\
\text { (2-tailed) }\end{array}$ & & .031 \\
\hline & $N$ & 177 & 177 \\
\hline \multirow[t]{3}{*}{ Konsentrasi } & $\begin{array}{l}\text { Correlation } \\
\text { Coefficient }\end{array}$ & $.162^{*}$ & 1.000 \\
\hline & $\begin{array}{l}\text { Sig. } \\
\text { (2-tailed) }\end{array}$ & .031 & \\
\hline & $N$ & 177 & 177 \\
\hline
\end{tabular}

Pada tabel 6 dapat kita lihat bahwa hasil uji korelasi antara kebiasaan sarapan pagi dengan konsentrasi belajar mahasiswa adalah sangat lemah dengan nilai koefisien korelasi (r) 0,162 namun signifikan pada alpha 5\% dengan $p$ value 0,031 dan arah korelasi yang positif.

\section{PEMBAHASAN}

Sarapan merupakan bagian dari pedoman umum gizi seimbang yang disampaikan oleh Kementerian Kesehatan Republik Indonesia pada tahun 2014, hal tersebut disebabkan oleh kenyataan bahwa banyak orang 
Indonesia belum terbiasa sarapan. Hasil deskriptif penelitian ini sesuai dengan fakta tersebut, yaitu dominan responden jarang melakukan sarapan sebelum beraktifitas. Berbagai alasan yang membuat mereka tidak atau jarang sarapan adalah terlambat bangun pagi, tidak sempat karena aktifitas kuliah jam 7 pagi, tidak terbiasa sarapan, merasa sakit perut jika sarapan, malas, sibuk kerja (labor), dan tidak sesuai selera. Alasanalasan tersebut sebenarnya dapat dikontrol oleh masing-masing individu jika mampu mengatur waktu atau jadwal kegiatan harian dengan baik dan teratur dan mulai belajar rutin sarapan tiap hari sehingga tubuh dan pikiran terbiasa dengan sarapan.

Proses kegiatan dalam belajar membutuhkan perhatian tinggi pada objek yang dipelajari. Kondisi fisik menjadi faktor yang sangat penting dalam menentukan tingkat perhatian mahasiswa yang dapat berdampak pada pencapaian tujuan kegiatan pembelajaran. Kondisi fisik tersebut ditentukan oleh asupan nutrisi melalui sarapan yang diserap dan diolah menjadi energi dalam mencapai kinerja otak yang optimal. Kegiatan mahasiswa yang membutuhkan banyak energi adalah proses pembelajaran di kelas, pelaksanaan praktikum hingga kegiatan ekstrakurikuler di luar kelas. Sarapan menjadi sangat penting karena dapat memberikan nutrisi harian yang dibutuhkan oleh tubuh pada pagi hari, salah satu bentuk nutrisi dominan yang disediakan saat sarapan adalah pemberian karbohidrat dan protein, maka karbohidrat ini akan dipertahankan menjadi glukosa untuk pemenuhan kebutuhan harian energi (Santoso, 2019).

Temuan hasil dalam penelitian ini membuktikan bahwa terdapat korelasi yang bermakna meskipun keeratan sangat lemah antara kebiasaan sarapan dengan konsentrasi belajar mahasiswa dengan arah korelasi positif, artinya semakin sering melakukan sarapan maka semakin meningkat kemampuan untuk berkonsentrasi saat belajar dan sebaliknya semakin tidak sarapan maka kemampuan konsentrasi akan berkurang. Hasil penelitian ini mendukung beberapa penelitian terdahulu yang dilakukan oleh Risda (2019) yaitu terdapat hubungan yang bermakna antara sarapan konsentrasi belajar pada mahasiswa, begitupula penelitian dari Verdina dan Muniroh (2017) menunjukkan adanya hubungan signifikan antara kebiasaan sarapan dengan tingkat konsentrasi belajar, dimana proporsi siswa dengan tingkat konsentrasi yang baik lebih tinggi pada mereka yang memiliki kebiasaan sarapan yang sehat dibandingkan dengan yang sekedar sarapan dan tidak sarapan.

Peningkatan konsentrasi belajar dapat dicapai melalui kegiatan sarapan yang erat kaitannya dengan mental yang cerdas, mampu memberikan nilai positif pada aktivitas otak, lebih peka dan lebih mudah untuk berkonsentrasi (Gayatri, Sumarni, dan Mutiarasari, 2018). Sarapan yang dikonsumsi peserta didik setidaknya menyuplai kebutuhan gizi sebesar 15\%-20\% dari kebutuhan gizi harian per individu (Hardinsyah \& Aries, 2012).

Konsentrasi seabagai salah satu aspek yang mendukung mahasiswa dalam meningkatkan pencapaian prestasi yang lebih baik, jika kemampuan konsentrasi berkurang maka kemampuan dalam mengikuti pelajaran di kelas maupun belajar secara mandiri akan terganggu. Melewatkan waktu sarapan dapat menyebabkan tubuh kekurangan glukosa sebagai sumber energi utama dalam melakukan aktifitas setiap hari. Hal ini dapat mempengaruhi seluruh organ termasuk otak (Lestari, 2019). 
Sarapan telah diklaim dapat meningkatkan fungsi kognitif dan kinerja akademik, namun masih kurangnya studi intervensi yang menilai jenis sarapan apa yang optimal untuk kinerja tersebut. Penelitian yang dilakukan oleh Sünram-Lea (2019) mengenai dampak respon glikemik berbasis sarapan pada kognisi menunjukkan bahwa profil glukosa darah yang lebih stabil bersirkulasi dikaitkan dengan fungsi kognitif yang lebih baik di pagi hari. Melewatkan sarapan mungkin berdampak pada fungsi kognitif, seperti gangguan kapasitas dasar fungsi eksekutif dalam mengendalikan respons otomatis (Sámano et al. 2019).

Meskipun bukti temuan hasil penelitian ini didapati adanya korelasi antara kebiasaan sarapan dengan konsentrasi belajar mahasiswa, masih banyak keterbatasan kemampuan peneliti untuk menarik kesimpulan dari temuan sebelumnya, bahwa studi yang berbeda secara luas sehubungan dengan karakteristik subjek, pengukuran variabel, dan waktu pelaksanaan penelitian. Keterbatasan dalam penelitian ini adalah penilaian kebiasaan sarapan pagi mahasiswa hanya berdasarkan frekuensi tiap hari dalam seminggu dan tidak menilai unsur gizi yang terkandung pada setiap jenis makanan yang dikonsumsi saat sarapan.

\section{KESIMPULAN DAN SARAN}

Kebiasaan sarapan yang rutin berkorelasi positif dengan tingkat konsentrasi belajar mahasiswa dibandingkan dengan yang jarang bahkan tidak pernah melakukan sarapan. Dominan responden yang rutin melakukan sarapan memiliki tingkat konsentrasi belajar yang baik dibandingkan dengan responden yang memiliki kebiasaan jarang dan tidak sarapan.
Peran orang tua, wali, kepala asrama, dan bahkan para pendidik sangat penting dalam mendukung mahasiswa untuk terbiasa melakukan sarapan sehat secara rutin. Selain itu, kesadaran mahasiswa terhadap pentingnya sarapan juga perlu ditingkatkan melalui sosialisasi baik di asrama dan di dalam maupun di luar kelas. Sarapan tidak hanya sekedar dilakukan tetapi perlu diperhatikan kualitas gizi yang terkandung dalam makanan, oleh karena itu disarankan untuk penelitian selanjutnya menganalisis kandungan gizi pada makanan yang dikonsumsi saat sarapan sebagai variabel penelitian.

\section{DAFTAR PUSTAKA}

Arifin, L. A., Prihanto, J. B. (2015). Hubungan sarapan pagi dengan konsentrasi belajar siswa di sekolah. Jurnal Pendidikan Olahraga dan Kesehatan Vol. 3, No. 1, 203-207. Diakses dari https://jurnalmahasiswa.unesa.ac.id/index. php/jurnal-pendidikanjasmani/article/view/13512/12408

Evans, S. (2009). Nutrition a lifespan approach. British Library: Wiley-Blackwell.

Faizah, S.N. (2014). Hubungan antara kebiasaan sarapan pagi dan kebiasaan jajan terhadap prestasi belajar siswa Sekolah Dasar SDN Banyuanyar III Surakarta. Diakses dari eprints. ums.ac.id/22216/14/NASKAH_PUBLIKA SI. pdf

Gayatri, C., Sumarni, Mutiarasari, D. (2018). Hubungan sarapan dengan konsentrasi siswa SDN Gtondo Palu Sulawesi Tengah. Medika Tadulako, Jurnal Ilmiah Kedokteran, Vol.5 No.3 September 2018. Palu: UNTAD. Diakses dari http://jurnal.untad.ac.id/jurnal/index.php/M edikaTadulako/article/download/12323/960 7 
Hardinsyah, \& Aries, M. (2012). Jenis pangan sarapan dan perannya dalam asupan gizi harian anak usia 6-12 tahun di Indonesia. Jurnal Gizi dan Pangan, 7(2), 89-96. Diakses dari http:// journal.ipb.ac.id/index.php/jgizipangan/articl el view/12370/9455

Kemenkes RI. (2014). Peraturan Menteri Kesehatan Republik Indonesia Tahun 2014 tentang pedoman gizi seimbang nomor 41. Diakses dari http://www.hukor.depkes.go.id/

Lestari, A. D. (2019). Hubungan sarapan pagi dengan konsentrasi belajar di SMK Bumantara Muntilan Jurusan Farmasi. Repository UNY. Diakses dari http://repository2.unw.ac.id/446/

Nurhadi, M. (2016). Hubungan antara Sarapan Pagi dengan Tingkat Konsentrasi Belajar Siswa di SDN Jatisari III Kecamatan Senori Kabupaten Tuban. LPPM STIKESNU. Diakses dari http://lppm.stikesnu.com/wpcontent/uploads/2016/02/5.-SarapanPagi.pdf

Peraturan Menteri Kesehatan RI Nomor 41 tahun 2014. Diakses dari http://hukor.kemkes.go.id/uploads/produk hukum/PMK\%20No.\%2041\%20ttg\%20Pe-d oman\%20Gizi\%20Seimbang.pdf

Risda, H. M. (2019). Hubungan sarapan dengan konsentrasi belajar pada mahasiswi kebidanan Fakultas Kedokteran Universitas Andalas. E-skripsi, Universitas Andalas. Diakses dari http://scholar.unand.ac.id/id/eprint/51849

Sámano, R., Hernández-Chávez, C., Chico Barba, G., Córdova-Barrios, A., Moralesdel-Olmo, M., Sordo-Figuero, H., Hernández, M., Merino-Palacios, C., Cervantes-Zamora, L., Martínez-Rojano,
H. (2019). Breakfast Nutritional Quality and Cognitive Interference in University Students from Mexico City. Int. J. Environ. Res. Public Health, 16, 2671. DOI: https://doi.org/10.3390/ijerph16152671

Santoso, R. (2019). Hubungan sarapan pagi dengan tingkat antensi. Eprints UMY. Diakses dari http://eprints.umm.ac.id/58068/

Setiawan, M.N \& Haridito, I. (2015). Hubungan status gizi dengan tingkat kosentrasi belajar siswa. E-Journal Unesa-Jurnal Kesehatan Olahraga, 3(1), 12-20. Diakses dari: http:// ejournal.unesa.ac.id/

Sukiniarti. (2015). Kebiasaan makan pagi pada anak usia SD dan hubungannya dengan tingkat kecerdasan. Jurnal Pendidikan Biologi Indonesia, 1(3), 315-321. Diakses dari http:// download.portalgaruda.org/article

Sünram-Lea S.I. (2019). Breakfast, glycemic index, and cognitive function in school children: evidence, methods, and mechanisms. Nestlé Nutrition Institute Workshop Series Vol.91. pp 169-178. Switzerland: Nestlé Nutrition Institute. DOI: https://doi.org/10.1159/000493708

Verdiana, L., Muniroh, L. (2017). Kebiasaan sarapan berhubungan dengan konsentrasi belajar pada siswa SDN Sukoharjo I Malang. Media Gizi Indonesia, Vol. 12, No. 1. hlm. 14-20. Diakses dari https://ejournal.unair.ac.id/MGI/article/download/3 $501 / 4669$

Wiarto, G. (2013). Budaya hidup sehat. Yogyakarta: Gosyen Publishing.

Winata, H. Y. (2015). Hubungan perilaku sarapan dengan konsentrasi belajar mahasiswa tahun ketiga program studi ilmu keperawatan Universitas Muhammadiyah Yogyakarta. Yogyakarta: UMY. Diakses dari 


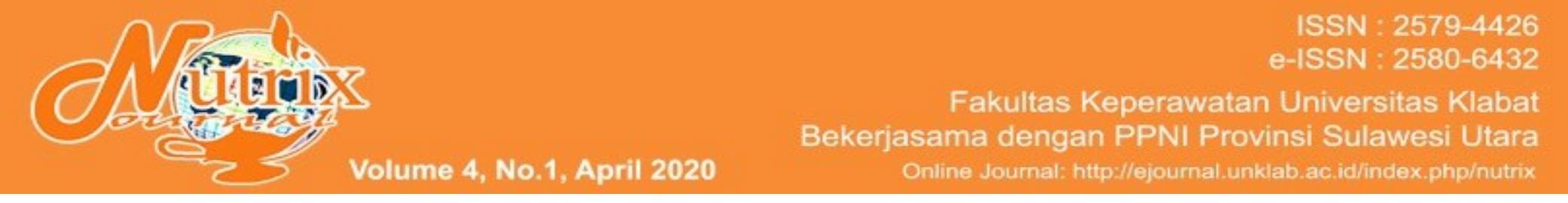

http://thesis.umy.ac.id/datapublik/t53268.pd f 